\title{
Extent of oxidative modification of low density lipoprotein determines the degree of cytotoxicity to human coronary artery cells
}

\author{
S A Thorne, S E Abbot, P G Winyard, D R Blake, P G Mills
}

\begin{abstract}
Objective-To assess whether the extent of LDL oxidation influences its cytotoxic effects, thus contributing to its atherogenic potential.

Design and setting-The effects of native and modified LDL on cultured human coronary artery smooth muscle cells (SMC) and endothelial cells (ECs) were investigated.
\end{abstract}

Main outcome measures-Four indices of cytotoxicity were studied: (i) chromium51 release; (ii) 5-bromo-2'-deoxyuridine (BrDUrd) uptake; (iii) morphological appearance; and (iv) EC migration. Results-(i) Minimally modified (mm) LDL $(400 \mu \mathrm{g} / \mathrm{ml})$ causes significant ${ }^{51} \mathrm{Cr}$ release; the cytotoxic effect was significantly greater for copper oxidised (ox) LDL $(400 \mu \mathrm{g} / \mathrm{ml})$. Native LDL had no effect. (ii) BrDUrd uptake studies showed significant inhibition of cell proliferation by $100 \mu \mathrm{g} / \mathrm{ml}$ of oxLDL and to a lesser extent by mmLDL; native LDL had no effect. (iii) Morphological appearance was not altered by native LDL. Changes in cell morphology were induced by mmLDL $(400 \mu \mathrm{g} / \mathrm{ml})$, and were more pronounced with oxLDL in concentrations of $\geqslant 200 \mu \mathrm{g} / \mathrm{ml}$. (iv) EC migration was significantly inhibited by oxLDL $(100 \mu \mathrm{g} / \mathrm{ml})$, but not by native or mmLDL.

Conclusion-The extent of oxidation of LDL determined its cytotoxicity to coronary artery cells. Native LDL had no cytotoxic effect. In contrast, oxLDL and to a lesser extent mmLDL caused cytotoxicity at concentrations to which cells in vivo might be exposed. This may contribute to the atherogenicity of modified LDL by enhancing cellular injury and inflammation, and by inhibiting re-endothelialisation of areas of coronary artery damaged during the atherogenic process.

(Heart 1996;75:11-16)

Keywords: oxidised low density lipoprotein; cytotoxicity; coronary artery

Modified low density lipoprotein (LDL) is implicated early in atherogenesis, accumulating in tissue macrophages to form foam cells, the hallmark of the fatty streak. ${ }^{1}$ Foam cell formation may be considered a physiological rather than a pathological process, with macrophages removing the atherogenic modified LDL from the intimal extracellular space. It is only when macrophage foam cell death occurs that LDL is released into the intima, a necrotic core forms, and an atherosclerotic plaque develops from the reversible fatty streak. Free intimal modified LDL may cause endothelial cytotoxicity, contributing to the endothelial dysfunction which characterises early atheromatous disease. ${ }^{2}$ Furthermore, as the atherosclerotic plaque progresses, more modified LDL accumulates and intimal smooth muscle cells (SMCs) die, increasing the lipid to smooth muscle ratio and the vulnerability of the plaque to rupture. ${ }^{3}$ It is thus important to understand the mechanism of cell death that characterises the developing plaque. Two possibilities exist, namely, apoptosis and necrosis. ${ }^{4}$ This paper considers the latter mechanism and the possibility that it may be the result of modified LDL induced cytotoxicity. As atherosclerosis has a predilection for the coronary circulation, we investigated this phenomenon in cultured human coronary artery SMCs and endothelial cells (ECs).

The initial egress of LDL into the intima is likely to comprise native or only minimally modified (mm) LDL. In the microenvironment of the arterial intima, however, LDL is protected from circulating antioxidants and exposed to macrophages, ECs, and SMCs, all of which can further oxidise LDL. ${ }^{56}$ Three forms of LDL were therefore used in this study: native, mmLDL, and copper oxidised (ox) LDL. MmLDL and oxLDL represent extremes of spectrum of modified LDL; mmLDL has undergone only minor lipid peroxidation, whereas major lipid peroxidation and oxidation of the apolipoprotein B moiety characterise oxLDL. ${ }^{7-9}$

Both mmLDL and oxLDL selectively induce monocyte chemotaxis, adhesion to, and transmigration across the arterial wall into the intima ${ }^{710}$ as well as macrophage proliferation within the atherosclerotic plaque. ${ }^{11}$ OxLDL also causes detrimental vasomotor effects, including endothelin synthesis, ${ }^{12}$ and impaired endothelium dependent relaxation responses. ${ }^{1314}$ Furthermore, oxLDL may mediate a local thrombotic tendency within the plaque, by inducing plasminogen activator inhibitor and stimulating tissue factor expression in the endothelium. ${ }^{15} 16$ As modified LDL is present in abundance in foam cells and throughout the stages of development of the atherosclerotic plaque, any cytotoxic effects on Cardiothoracic Unit, Hospital for Sick Children, Great Ormond Street, Accepted for publication 24 July 1995 
intimal cells may further contribute to inflammation and disease progression.

\section{Methods}

All reagents were obtained from Sigma Chemicals (Poole, UK) unless otherwise stated.

\section{CELL CULTURE}

Normal human coronary arteries were obtained from cardiac explants and all experiments were conducted using cells at or before the third passage. Media were from Gibco Life Technology (Paisley, UK). ECs were isolated from coronary artery segments ${ }^{17}$ and maintained in culture in medium 199 with $20 \%$ fetal calf serum. Intimal coronary artery SMCs were cultured using a modification of an explant method ${ }^{18}$ and maintained in Dulbecco's modified Eagle medium with $10 \%$ fetal calf serum.

\section{LDL PREPARATION}

LDL isolation

LDL was isolated by potassium bromide density gradient ultracentrifugation of the serum from healthy adult donors, in the presence of $1 \mathrm{mmol} / 1$ EDTA. ${ }^{19}$ The LDL fraction was dialysed and the protein content determined. ${ }^{20}$ $\mathrm{LDL}$ isolates were shown by electrophoresis to be free from contaminating very low density lipoproteins and high density lipoproteins subfractions, which might alter their biological properties. ${ }^{21-23}$

\section{$L D L$ endotoxin content}

LDL isolation procedures were performed using sterile techniques and pyrogen free equipment to minimise endotoxin contamination. ${ }^{24}$ The lipopolysaccharide (LPS) content of isolated LDL was assessed by the Limulus amoebocyte lysate assay ${ }^{25}$ and was $<30 \mathrm{pg} / \mathrm{ml}$ in all preparations. We showed that this was insufficient to induce cytotoxicity or adhesion molecule expression in endothelial or SMCs. ${ }^{26} 27$ Figure 1 illustrates that $\geqslant 100$ $\mathrm{pg} / \mathrm{ml}$ LPS induced expression of E-selectin, vascular cell adhesion molecule-1, and intercellular adhesion molecule-1 in ECs (and vascular cell adhesion molecule-1 and intercellular adhesion molecule-1 expression in SMCs, data not shown). Experiments ( $n=3$ for each cell type) were performed in triplicate.

\section{Modification of $L D L$}

LDL fractions were oxidised by incubation with $16.6 \mu \mathrm{mol} / 1$ copper sulphate per $100 \mu \mathrm{g} / \mathrm{ml} \mathrm{LDL}$ at room temperature for $10 \mathrm{~h},{ }^{8}$ and shown to have undergone a high degree of lipid peroxidation by spectrophotometric monitoring of the formation and subsequent decomposition of conjugated dienes ${ }^{28}$ and by a rise in thiobarbituric acid reactive substances to $>20 \mathrm{nmol}$ malonaldehyde/mg LDL protein. ${ }^{29}$ Increased electrophoretic mobility confirmed oxidation of the LDL protein moiety (Paragon electrophoresis systems, Beckman Instruments, Palo Alto, USA). Minimal modification of LDL was achieved by prolonged ( $>3$ months) storage at $4^{\circ} \mathrm{C}^{4}$ and confirmed by a

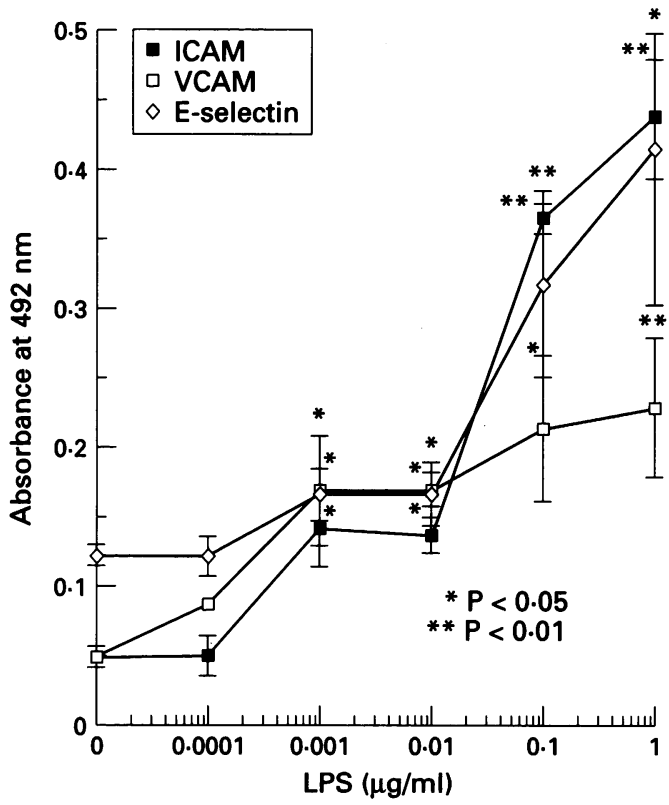

Figure 1 Effect of lipopolysaccharide (LPS) on endothelial adhesion molecule expression in coronary artery endothelial cells. Significant $(\boldsymbol{P}<0.05)$ VCAM-1, ICAM-1, and E-selectin expression was induced by $0.001 \mu \mathrm{g} / \mathrm{ml} \mathrm{LPS}$ and followed a dose-response pattern. Adhesion molecule expression was not induced by $\leqslant 0.0001 \mu \mathrm{g} / \mathrm{ml}(100 \mathrm{pg} / \mathrm{ml})$ LPS. Experiments $(n=3)$ were performed in triplicate. VCAM, vascular cell adhesion molecule; ICAM, intercellular adhesion molecule.

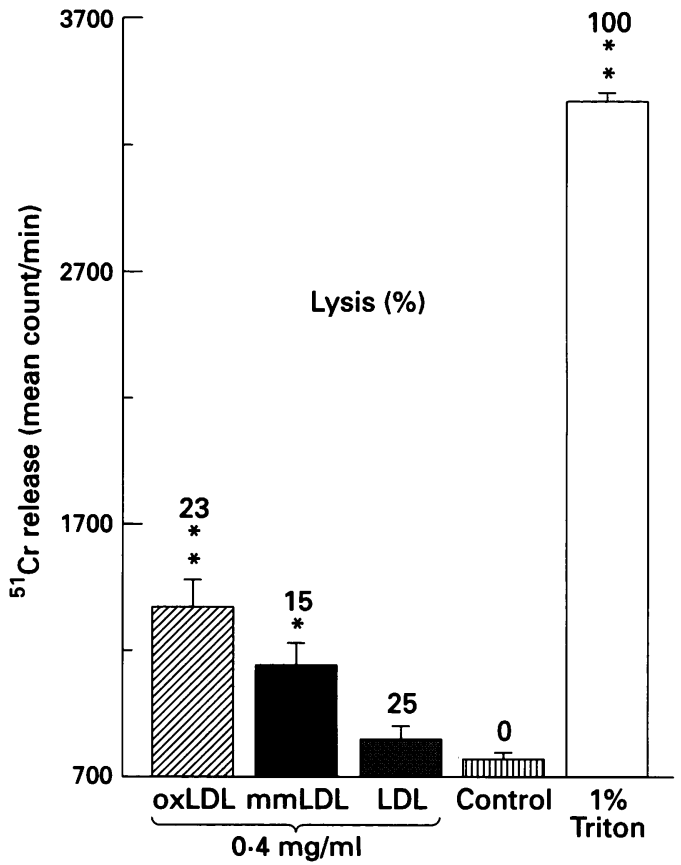

Figure 2 Quantification of low density lipoprotein (LDL) cytotoxicity in coronary artery smooth muscle cells by chromium-51 release. Minimally modified $(\mathrm{mm}) \mathrm{LDL}$ $(400 \mu \mathrm{g} / \mathrm{ml})$ caused a significant $(* P<0.05)$ increase in ${ }^{51} \mathrm{Cr}$ release. Copper oxidised LDL (oxLDL) (400 $\left.\mu \mathrm{g} / \mathrm{ml}\right)$ also caused a significant $(* \star P<0.01)$ increase in ${ }^{51} \mathrm{Cr}$ release, which was significantly greater $(P<0.05)$ than $m m L D L$. These data correspond to $23 \%$ lysis for ox $L D L$ and $15 \%$ for $m m L D L$. Native $L D L$ did not induce significant ${ }^{51} \mathrm{Cr}$ release. 


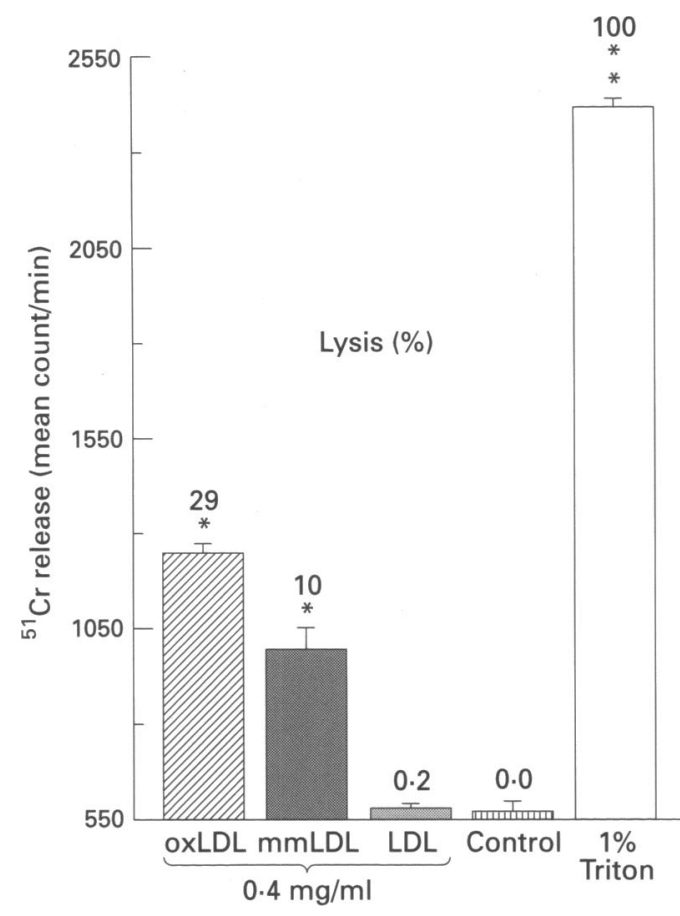

Figure 3 Quantification of low density lipoprotein (LDL) cytotoxicity in coronary artery endothelial cells by ${ }^{51} \mathrm{Cr}$ release. Minimally modified $(\mathrm{mm}) \mathrm{LDL}(400 \mathrm{\mu g} / \mathrm{ml})$ caused a significant $\left({ }^{\star} P<0.01\right)$ increase in ${ }^{51} \mathrm{Cr}$ release compared with that of the negative control. Copper oxidised LDL (oxLDL) $(400 \mu \mathrm{g} / \mathrm{ml})$ also caused a significant $\left({ }^{*} P<0.01\right)$ increase in ${ }^{51} \mathrm{Cr}$ release, which was significant $\left({ }^{*} P<0.01\right)$ increase in $\mathrm{Cr}$ release, which was
significantly $(P<0.05)$ greater than $\mathrm{mmLDL}$. These data correspond to $29 \%$ and $10 \%$ cell lysis for oxLDL and $m m L D L$, respectively. Native $L D L$ did not induce significant ${ }^{5} \mathrm{C}$ Cr release, being associated with $0 \cdot 2 \%$ cell lysis.

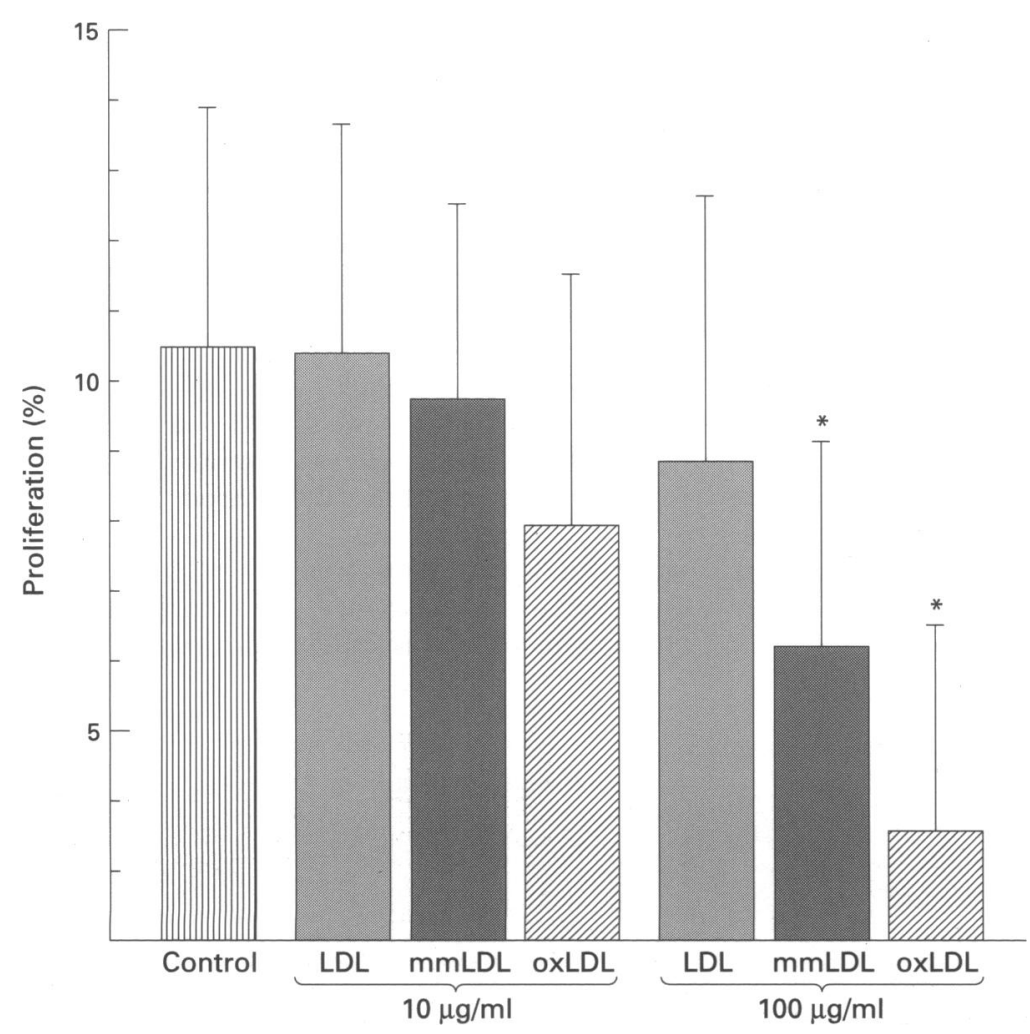

Figure 4 Effect of low density lipoprotein $(L D L)$ on coronary artery endothelial cell proliferation. Both copper oxidised $(o x)$ and minimally modified $(\mathrm{mm}) L D L(100 \mu \mathrm{g} / \mathrm{ml})$ significantly inhibited proliferation $\left({ }^{\star} P<0.01\right)$. OxLDL inhibited proliferation significantly more than did $m m L D L(P<0.05)$. Native $L D L$ did not influence proliferation. small increase in thiobarbituric acid reactive substances $\quad(5-20 \mathrm{nmol}$ malonaldehyde $/ \mathrm{mg}$ LDL protein) compared with that in native LDL ( $<4$ nmol malonaldehyde/mg LDL protein), with no increase in conjugated diene content or electrophoretic mobility.

\section{CYTOTOXICITY ASSAYS}

Chromium - 51 release

The ${ }^{51} \mathrm{Cr}$ release assay quantifies severe cytotoxicity, detecting cell membrane disruption or cell lysis. ECs or SMCs were grown to confluence on 96 well plates. The growth medium was replaced with $100 \mu \mathrm{l}$ of fresh medium with the addition of $300 \mu \mathrm{Sv}$ sodium ${ }^{51}$ chromate $\left({ }^{51} \mathrm{Cr}\right) /$ well, and the cells incubated for $90 \mathrm{~min}$ at $37^{\circ} \mathrm{C}$. The ${ }^{51} \mathrm{Cr}$ containing medium was replaced with $100 \mu \mathrm{l} /$ well of fresh medium containing $0-400 \mu \mathrm{g} / \mathrm{ml}$ of native or modified LDL, or a positive control ( $1 \%$ Triton), and the cells were incubated for $5 \mathrm{~h}$. Experiments ( $n=3$ for each cell type) were performed in triplicate. Cytotoxic effects were quantified by measuring ${ }^{51} \mathrm{Cr}$ release from cells using a Beckman 550 gammacounter.

\section{5-Bromo-2'-deoxyuridine uptake}

The assay identifies cells in the S (DNA synthesis) phase of the cell cycle. Cells were seeded onto a 96 well plate at a density of 5000 cells/wells in their usual growth medium, with the addition of native or modified LDL $(0-100 \mu \mathrm{g} / \mathrm{ml})$. After the addition of $10^{-5} \mathrm{~mol} / 1$ 5-bromo-2'-deoxyuridine (BrDUrd) they were incubated for 10 (ECs) or $18 \mathrm{~h}$ (SMCs). Cells were fixed and hydrolysed before immunocytochemical staining using mouse monoclonal antibody to BrDUrd (Dakopatts, High Wycombe, UK) and counterstaining with toluedine blue. Random quadrant sampling was used to assess the percentage of positive cells in each well. Experiments $(n=4$ for each cell type) were performed in triplicate.

\section{Morphological appearance}

Photomicrographs were taken at hourly intervals during the above ${ }^{51} \mathrm{Cr}$ release assays to document LDL induced morphological changes in the cells.

\section{Migration assay}

The effects of LDL on EC migration were quantified using a method previously developed in this laboratory. ${ }^{30}$ Briefly, ECs were grown to confluence onto fibronectin coated Thermanox (Nunc, Naperville, Illinois, USA) coverslips. A strip of cells was removed with a $1.4 \mathrm{~mm}$ resin scraper and remaining cells were incubated for up to $30 \mathrm{~h}$ in medium M199 with $10 \%$ fetal calf serum, with additions of native and modified LDL $(0-200 \mu \mathrm{g} / \mathrm{ml})$. Migration was assessed by sequential photography and quantified by measuring the change in wound width during the incubation period. For each strip, seven random width measurements were taken at each time point, and the mean percentage change in width calculated. Experiments $(n=5)$ were performed in duplicate. The technique was unsuitable for cultures of SMCs; because of their large size 


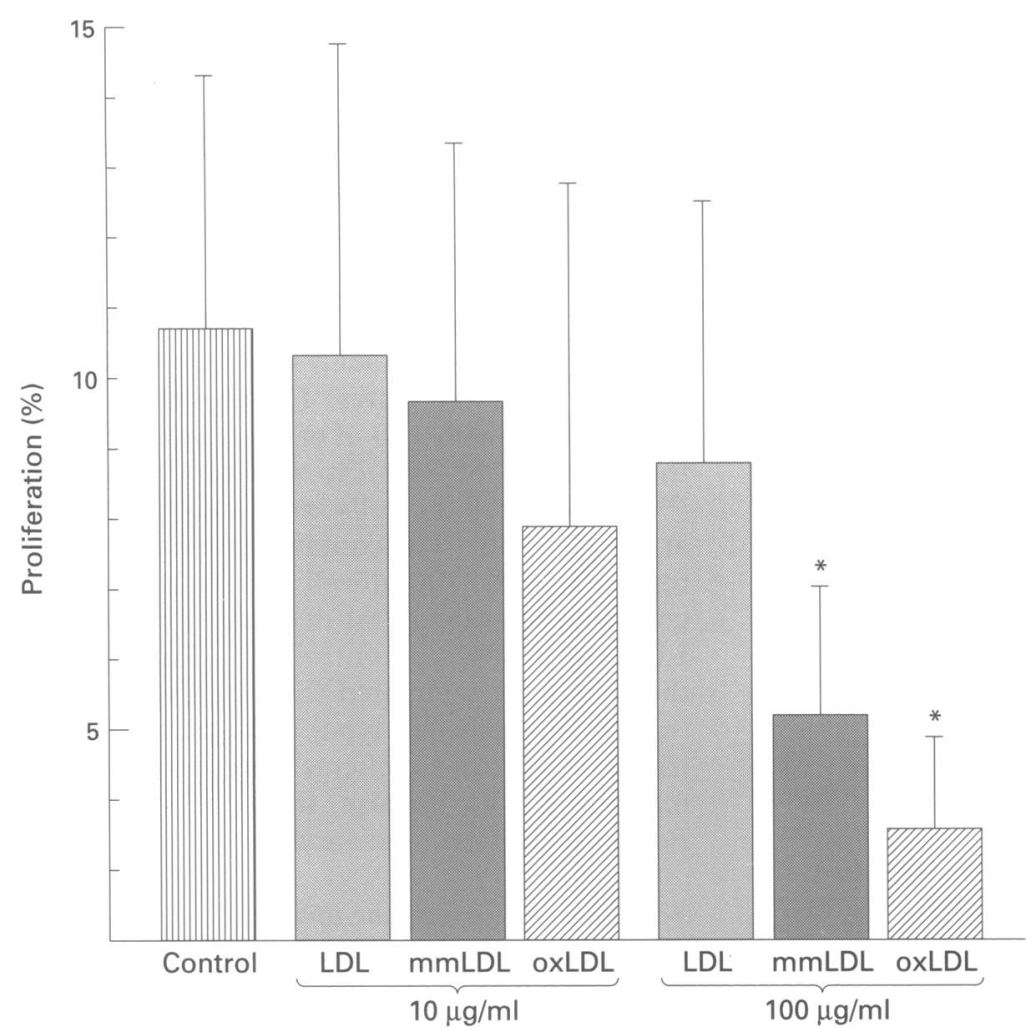

Figure 5 Effect of low density lipoprotein (LDL) on coronary artery smooth muscle cell proliferation. Both copper oxidised (ox) and minimally modified $(\mathrm{mm}) \mathrm{LDL}(100 \mu \mathrm{g} / \mathrm{ml})$ significantly inhibited proliferation $\left({ }^{\star} P<0.05\right)$. OxLDL caused a significantly greater decrease in proliferation than did $m m L D L(P<0.05)$. Native $L D L$ did not influence proliferation. and strong intercellular connections it was not possible to remove a strip of cells and leave edges from which migration could be assessed.

\section{STATISTICAL ANALYSIS}

Data are expressed as mean (SD). Statistical analysis of data was performed by one way analysis of variance, and significance inferred at a $p$ value of $<0.05$.

\section{Results}

${ }^{51}$ CR RELEASE

Figures 2 and 3 illustrate results from representative experiments. Native LDL did not induce ${ }^{51} \mathrm{Cr}$ release in concentrations up to $400 \mu \mathrm{g} / \mathrm{ml}$. Both oxLDL and mmLDL caused significant ${ }^{51} \mathrm{Cr}$ release at $400 \mu \mathrm{g} / \mathrm{ml}$; oxLDL caused significantly greater release than $\mathrm{mmLDL}$.

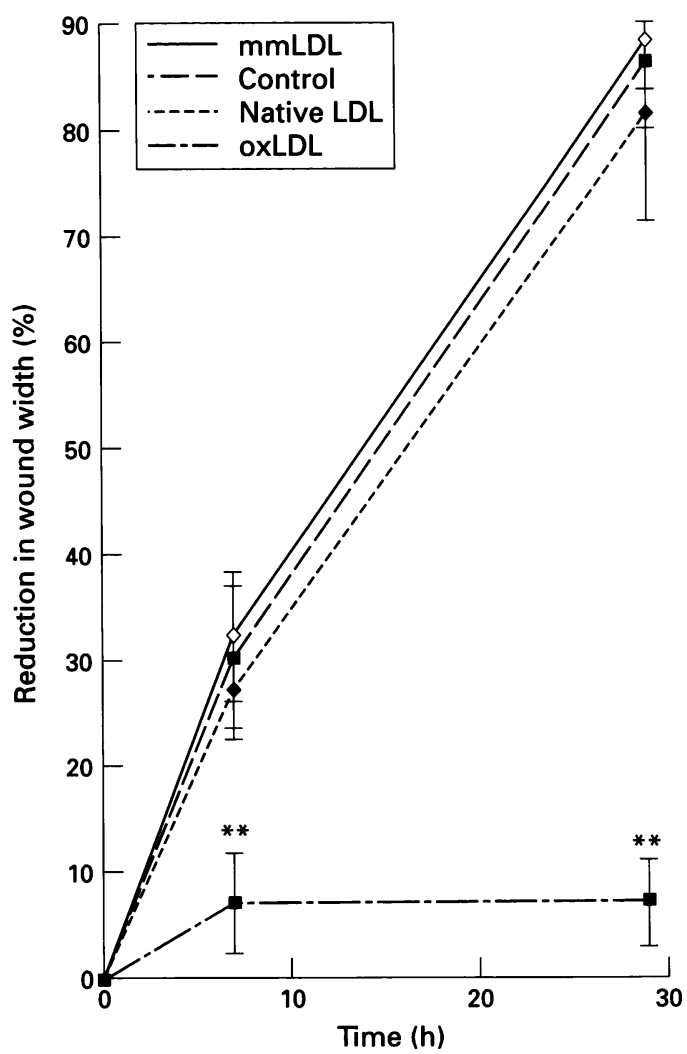

Figure 7 Effects of low density lipoprotein (LDL) on coronary artery endothelial cell (EC) migration. Reduction in wound width was due to migration of cells into the wound space. EC migration was significantly $(* * P<0.0001$ ) inhibited by copper oxidised (ox) LDL at 7 and $29 \mathrm{~h}$. Native and minimally modified $(\mathrm{mm}) \mathrm{LDL}$ did not affect migration. Experiments $(n=4)$ were performed in duplicate.

\section{BrDUrd uptake}

Figures 4 and 5 illustrate results from representative experiments. Native LDL had no effect on coronary artery EC or SMC proliferation in concentrations up to $100 \mu \mathrm{g} / \mathrm{ml}$. In contrast, oxLDL and mmLDL at $100 \mu \mathrm{g} / \mathrm{ml}$ significantly inhibited SMC and EC proliferation. The inhibitory effect of oxLDL was significantly greater than mmLDL. In addition, morphological changes were observed in SMCs and ECs incubated in oxLDL $(100 \mu \mathrm{g} / \mathrm{ml})$, with cells beginning to retract towards the end of the study period.

\section{MORPHOLOGICAL APPEARANCE}

Qualitative assessment of morphological changes in cells was made from photomicro-
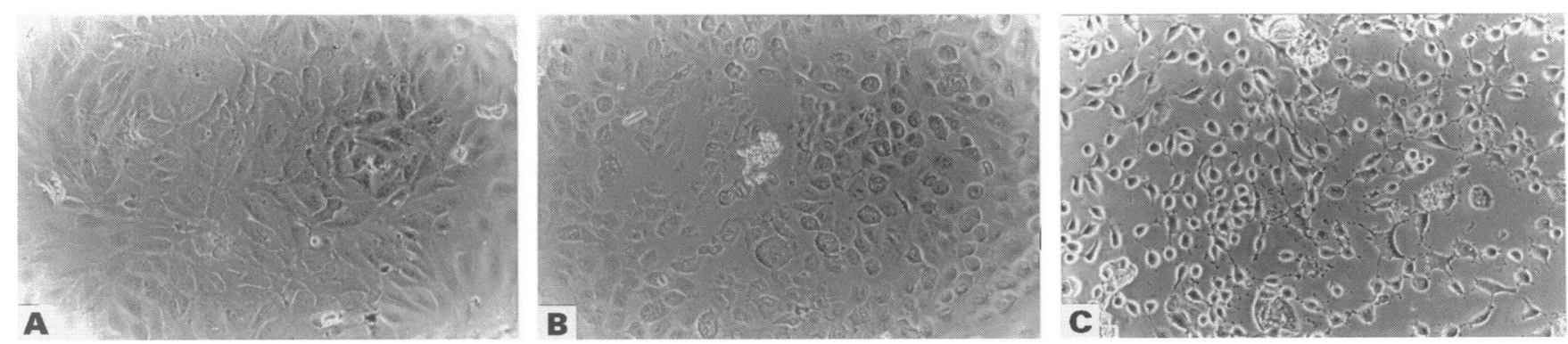

Figure 6 Phase contrast photomicrographs of endothelial cells showing morphological change after 5 h incubation with $400 \mu$ g/ml low density lipoprotein (LDL) preparations. (A) Native LDL. There is no visible disruption of the confluent monolayer. (B) Minimally modified LDL. Some retraction of cells has occurred. (C) Copper oxidised LDL. Retraction of cells is more pronounced and also associated with release of chromium-51. (Original magnification $\times 50)$. 
graphs. Figure 6 illustrates results for ECs. Native LDL induced no morphological abnormalities, but $5 \mathrm{~h}$ of incubation with $\geqslant 200 \mu \mathrm{g} / \mathrm{ml}$ of $\mathrm{mmLDL}$ and oxLDL caused morphological disruption. The effect was most pronounced for oxLDL: $200 \mu \mathrm{g} / \mathrm{ml}$ caused cells to retract and $400 \mu \mathrm{g} / \mathrm{ml}$ resulted in many cells becoming detached. The morphology of coronary artery SMCs was assessed in the same manner as that for ECs. Only cells incubated with oxLDL at a concentration of $400 \mu \mathrm{g} / \mathrm{ml}$ showed evidence of morphological change, beginning to retract after a $5 \mathrm{~h}$ incubation period.

\section{MIGRATION ASSAY}

As illustrated in fig 7, native and mmLDL had no effect on EC migration. Migration was significantly inhibited $(P<0.0001)$ in the presence of oxLDL $(100 \mu \mathrm{g} / \mathrm{ml})$. Lower concentrations of oxLDL had no effect on cell migration, and higher concentrations were frankly cytotoxic, causing widespread cell retraction and detachment.

\section{Discussion}

Modified LDL induced cytotoxicity in ECs and SMCs as assessed by the four methods studied, the degree of cytotoxicity being determined by the extent of LDL oxidation. Extensive copper ion oxidation of LDL lipid and protein moieties might be predicted to induce enhanced cytotoxicity. However, these studies have also demonstrated that even minimal modification of LDL resulted in a marked increase in cytotoxicity. Modified LDL produced biological effects at concentrations considerably lower than normal plasma LDL concentrations (600-700 $\mu \mathrm{g}$ LDL protein $/ \mathrm{ml}$ ) plasma), ${ }^{31}$ suggesting that intimal cells may be exposed to biologically significant levels of modified LDL in vivo. These data suggest that LDL contributes to cell death and inflammation within the atherosclerotic plaque by necrosis, rather than by apoptosis. ${ }^{4}$

${ }^{51} \mathrm{Cr}$ release quantified severe cytotoxic effects; the other three methods used assessed the non-lethal cytotoxic effects of modified LDL. Although only semiquantitative, assessment of morphological change was a more sensitive method of detecting cytotoxicity than ${ }^{51} \mathrm{Cr}$ release. Morphologically, ECs were more susceptible to modified LDL induced cytotoxicity than SMCs. This may be a consequence of the fact that cultured SMCs produce more matrix and stronger intercellular connections than do ECs.

EC migration is important in maintaining an intact endothelium in the healthy artery, and so any impairment of this function may reflect mild, but physiologically important, cytotoxicity. OxLDL significantly inhibited EC migration; native and $\mathrm{mmLDL}$ had no effect. If oxLDL also inhibits EC migration in vivo, it may prevent the re-endothelialisation of areas of coronary artery denuded of endothelium during the atherogenic process.

Assessment of cell proliferation by BrDUrd incorporation proved the most sensitive method of quantifying cytotoxicity; cellular DNA synthesis was inhibited by $100 \mu \mathrm{g} / \mathrm{ml}$ oxLDL and to a lesser extent by mmLDL, with no effect produced by native LDL. This contrasts with some other reports, ${ }^{32} 33$ which suggest that native and oxidised LDL may enhance SMC growth. This discrepancy may be explained by methodological differences. Firstly, in contrast to the work described here, the cells were cholesterol deficient and so the effects of the addition of LDL may merely reflect the return of cholesterol required for growth. Secondly, the cells used were at higher passage $(8-16)^{32}$ than ours, which may result in changes in growth characteristics. Thirdly, LDL preparations may have been contaminated with endotoxin, ${ }^{33}$ invalidating results (see later). Although cell proliferation was inhibited by oxLDL in our experiments, a monoculture system was used and it may be speculated that oxLDL activates other cell types within the atherosclerotic plaque to release SMC and EC mitogens, and therefore indirectly promotes cell proliferation.

Endotoxin contamination may invalidate cell culture experiments as LPS is a potent activator of cells, including endothelial tissue factor and adhesion molecule expression. ${ }^{1626}$ The LDL preparations used in these studies contained insufficient endotoxin to activate cells. It is noteworthy, however, that merely applying an aseptic technique does not prevent significant LPS contamination. Although some investigators have ensured low endotoxin levels, ${ }^{71622}$ others have not; ${ }^{51033}$ their results should therefore be interpreted with caution.

The antioxidant activity of plasma prevents significant oxidation of circulating LDL. However, the microenvironment of the early atherosclerotic plaque may be pro-oxidant; activated macrophages, ECs, and SMCs are all capable of modifying LDL. ${ }^{56}$ These studies have shown that although the degree of cytotoxicity is dependent on the extent of LDL oxidation, even minimal modification of $\mathrm{LDL}$ renders it toxic to coronary artery SMCs and ECs at biologically relevant concentrations. The results have clinical implications for the development of atherosclerotic disease. The endothelium damaged by modified LDL may have impaired abilities to maintain vascular tone and control permeability and cell adhesion, and damaged intimal SMCs may provoke the release of inflammatory mediators. Where cytotoxicity produces areas of endothelial denudation, the reduced migratory abilities of the remaining ECs may limit repair of the denuded area, exposing intimal SMCs to procoagulant and SMC growth factors, and contributing to the inflammatory process of atherosclerosis. In summary, we have found evidence that modified LDL causes cytotoxicity and may therefore have a role in the necrosis and inflammation that characterises the progressive atherosclerotic plaque.

SAT was funded by the The British Heart Foundation and a Bristol Myers Squibb cardiovascular research fellowship. SEA was funded by The Arthritis and Rheumatism Council, UK. UK, and The British Technology Group UK. 
1 Stary H. Evolution and progression of atherosclerotic lesions in coronary arteries of children and young adults. Arteriosclerosis 1989;9(suppl 1):I1-19.

2 Ross R. The pathogenesis of atherosclerosis: a perspective for the 1990s. Nature 1993;362:801-9.

3 Richardson $P$, Davies $M$, Born G. Influence of plaque configuration and stress distribution on fissuring of coronary atherosclerotic plaques. Lancet 1989;ii:941-4.

4 Isner JM, Kearney M, Bortman S, Passeri J. Apoptosis in human atherosclerosis and restenosis. Circulation 1995; 91:2703-11.

5 Morel DW, Hessler JR, Chislom GM. Low density lipoprotein cytotoxicity induced by free radical peroxidation of lipid. $\mathcal{F}$ Lipid Res 1983;24:1070-6.

6 Hiramatsu K, Rosen H, Heinecke JW, Wolfbauer G, Chai A. Superoxides initiate oxidation of low density lipoprotein by monocytes. Arteriosclerosis 1987;7:55-60.

7 Berliner JA, Territo MC, Sevanian A, Ramin S, Kim JA Bamshad B, et al. Minimally low density lipoprotein stimulates monocyte endothelial interactions. $f$ Clin Invest 1990;85:1260-6.

8 Esterbauer H, Dieber-Rotheneder M, Waeg G, Striegel G, Jürgens G. Biochemical, structural and functional prop-
erties of oxidised low-density lipoprotein. Chem Res Toxicol 1990;3:77-92

9 Goldstein JL, Ho YK, Basu SK, Brown MS. Binding site on macrophages that mediates uptake and degradation of acetylated low density lipoprotein producing massive cholesterol deposition. Proc Natl Acad Sci USA 1979;76: 333-7.

10 Quinn MT, Parthasarathy S, Fong LG, Steinberg D Oxidatively modified low density lipoproteins: a potentia role in recruitment and retention of monocyte macrophages during atherogenesis. Proc Natl Acad Sci USA 1987;84:2995-8.

11 Rajavashisth TB, Andalibi A, Territo MC, Berliner JA Navab M, Fogelman AM, et al. Induction of endothelia cell expression of granulocyte and macrophage colonystimulating factors by modified low density lipoproteins. Nature 1990;344:254-7.

12 Boulanger CM, Tanner FC, Béa ML, Hahn AWA, Werner $\mathrm{A}$, Lüscher TF. Oxidised low density lipoproteins induce mRNA expression and release of endothelin from human and porcine endothelium. Circ Res 1992;70:1191-7.

13 Simon BC, Cunningham LD, Cohen RA. Oxidised low density lipoproteins cause contraction and inhibit endothelium-dependent relaxation in the pig coronary artery. $\mathcal{F}$ Clin Invest 1990;86:75-9.

14 Flavahan NA. Atherosclerosis or lipoprotein-induced endothelial dysfunction. Circulation 1992;85(5):1927-37.

15 Latron Y, Chautan M, Anfosso F, Alessi MC, Nalbone G Lafont $\mathrm{H}$, et al. Stimulating effect of oxidised low density lipoproteins on plasminogen activator inhibitor-1 synthesis by endothelial cells. Arterioscler Thromb 1991;11(6): $1821-9$

16 Drake TA, Hannani K, Fei H, Lavi S, Berliner JA. Minimally modified low density lipoprotein induce tissue factor expression in cultured human endothelial cells. $\mathrm{Am} f$ Pathol 1991;138(3):601-7.

17 Jaffe EA, Nachman RL, Becker CG, Minick CR. Culture of human endothelial cells derived from umbilical veins. f Clin Invest 1973;52:2745-6.

18 Smirnov VN, Orekhov AN. Smooth muscle cells from adult human aorta. In: Piper HM, ed. Cell culture tech- niques in heart and vessel research. New York: SpringerVerlag, 1990:271-89.

19 Havel RJ, Eder HA, Bragdon JH. The distribution and chemical composition of ultracentrifugally separated lipoproteins in human serum. $\mathcal{F}$ Clin Invest 1955;34:1345-53.

20 Lowry OH, Rosebrough NJ, Farr AL, Randall RJ. Protein measurement with the Folin phenol reagent. $f$ Biol Chem 1951;193:265.

21 Territo MC, Berliner JA, Almada L, Ramirez R, Fogelman AM. $\beta$-very low density lipoprotein pretreatment of AM. $\beta$-very low density lipoprotein pretreatment of endothelial monolayers increa
Arteriosclerosis 1989;9:824-8.

22 Navab M, Imes SS, Hama SY, Gough GP, Ross LA, Bork $\mathrm{RW}$, et al. Monocyte transmigration induced by modification of low density lipoprotein in cocultures of human aortic wall cells is due to induction of monocyte chemotactic protein 1 synthesis and is abolished by high density lipoprotein. F Clin Invest 1991;88: $2039-46$.

23 Parthasarathy S, Barnett J, Fong LG. High-density lipoprotein inhibits the oxidative modification of low-density lipoprotein. Biochim Biophys Acta 1990;1044:275-83.

24 Ludwig JD, Avis KE. Dry heat inactivation of endotoxin on the surface of glass. $\mathcal{F}$ Parenter Sci Technol 1990;44(1): 4-12.

25 Yin ET, Galanos C, Kinsky S, Bradshaw RA, Wessler S, Lüderitz $\mathrm{O}$, et al. Picogram-sensitivity assay for endotoxin: gelation of Limulus polyphemus blood cell lysate induced by purified lipopolysaccharides and lipid A from gram-negative bacteria. Biochim Biophys Acta 1972;261: gram-n.

26 Bevilacqua MP, Pober JS, Mendrick DL, Cotran RS, Gimbrone MA. Identification of an inducible endothelial-leukocyte adhesion molecule. Proc Natl Acad Sci USA 1987;87:1188-92.

27 Wellicome SM, Thornhill MH, Pitzalis C, Thomas DS, Lanchbury JSS, Panayi GS, et al. A monoclonal antibody that detects a novel antigen on endothelial cells that is induced by tumour necrosis factor, $\mathrm{IL}-1$, or lipopolysaccharide. F Immunol 1990;144:2558-65.

28 Esterbauer $H$, Dieber-Rotheneder M, Waeg G, Puhl H, Tatzber $F$. Endogenous antioxidants and lipid peroxidation. Biochem Soc Trans 1990;18:1059-61.

29 Yagi K. Assay for serum lipid peroxide level and its clinical significance. In: Lipid peroxides in biology and medicine. New York: Academic Press, 1982:223-42.

30 Thorne SA, Abbot SE, Blake DR, Mills PG. Human recombinant tissue-type plasminogen activator enhances wound healing in human coronary artery endothelial cells [abstract]. Br Heart $\mathcal{F}$ 1992;68(1):

31 Havel RJ Kane JP. Structure and metabolism of plasma lipoproteins. In: Schriver CR, Beaudet AL, Sly WS, Valle $\mathrm{D}$, eds. The metabolic basis of inherited disease. New York: McGraw-Hill, 1989:1129-38.

32 Stiko-Rahm A, Hultgardh-Nilsson A, Regnstrom J, Hamsten A, Nilsson J. Native and oxidised LDL enhances production of PDGF AA and the surface expression of PDGF receptors in cultured human SMCs. Arterioscl Thromb 1992;12(9):1099-109.

33 Harris-Hooker S, Sanford GL, Montgomery V, Rivers R, Emmett $\mathbf{N}$. Influence of low density lipoproteins on vascular smooth muscle. Cell Biol Int Rep 1992;16(5): 